OPEN ACCESS

Edited by:

Dongyan Liu,

East China Normal University, China

Reviewed by:

Qiuying Han,

Hainan Tropical Ocean University,

China

Jennifer Li Ruesink, University of Washington,

United States

${ }^{*}$ Correspondence:

Yi Zhou

yizhou@qdio.ac.cn

${ }^{\dagger}$ These authors have contributed equally to this work

Specialty section: This article was submitted to Marine Ecosystem Ecology, a section of the journal Frontiers in Marine Science

Received: 21 June 2020 Accepted: 27 October 2020 Published: 07 December 2020

Citation:

Yue SD, Zhang XM, Xu SC, Zhang $Y$, Zhao $P$, Wang $X D$ and

Zhou Y (2020) Reproductive Strategies of the Seagrass Zostera japonica Under Different Geographic

Conditions in Northern China.

Front. Mar. Sci. 7:574790.

doi: 10.3389/fmars.2020.574790

\section{Reproductive Strategies of the Seagrass Zostera japonica Under Different Geographic Conditions in Northern China}

\author{
Shidong Yue ${ }^{1,2,3,4,55}$, Xiaomei Zhang 1,2,3,4t, Shaochun $X u^{1,2,3,4,5}$, Yu Zhang ${ }^{1,2,3,4,5}$, \\ Peng Zhao ${ }^{6}$, Xiaodong Wang ${ }^{7}$ and Yi Zhou ${ }^{1,2,3,4 *}$
}

${ }^{1}$ CAS Key Laboratory of Marine Ecology and Environmental Sciences, Institute of Oceanology, Chinese Academy of Sciences, Qingdao, China, ${ }^{2}$ Laboratory for Marine Ecology and Environmental Science, Qingdao National Laboratory for Marine Science and Technology, Qingdao, China, ${ }^{3}$ Center for Ocean Mega-Science, Chinese Academy of Sciences, Qingdao, China, ${ }^{4}$ CAS Engineering Laboratory for Marine Ranching, Institute of Oceanology, Chinese Academy of Sciences, Qingdao, China, ${ }^{5}$ University of Chinese Academy of Sciences, Beijing, China, ${ }^{6}$ State Key Laboratory of Marine Resource

Utilization in South China Sea, Hainan University, Haikou, China, ${ }^{7}$ Mashan Group Co., Ltd., Weihai, China

Seagrasses form a unique group of submerged marine angiosperms capable of both sexual and asexual reproduction. The amounts of sexual and asexual reproduction differ within some species relying on geographic location and environmental factors. Here, we studied the reproductive strategies of different geographic Zostera japonica populations, $\mathrm{S} 1$ and $\mathrm{S} 2$ at Swan Lake lagoon (SLL), and $\mathrm{H} 1$ and $\mathrm{H} 2$ at Huiquan Bay (HQB), in northern China. The duration of flowering at SLL was longer than at $H Q B$, whereas flowering initiation at HQB occurred earlier than at SLL. In addition, the timing of seed maturation at HQB occurred earlier than at SLL. The allocation to sexual reproduction at SLL was greater than at HQB. The maximum potential seed production was greatest at S1 $\left(22228.52 \pm 8832.46\right.$ seeds $\left.\cdot \mathrm{m}^{-2}\right)$, followed by S2 $(21630.34 \pm 9378.67$ seeds $\left.\cdot \mathrm{m}^{-2}\right), \mathrm{H} 2\left(7459.60 \pm 1779.33\right.$ seeds $\left.\cdot \mathrm{m}^{-2}\right)$, and H1 $(2821.05 \pm 1280.57$ seeds $\cdot \mathrm{m}^{-2}$ ). The seasonal changes in total shoot density and biomass were small at HQB. There was a relatively large number of overwintering shoots at HQB because of the higher average temperature during winter. The allocation to sexual reproduction was lower than at SLL, and no seedlings were observed at HQB during our study. Thus, the population of $Z$. japonica at HQB was maintained by asexual reproduction. Compared with HQB, the biomass of overwintering shoots at SLL was less than $30 \mathrm{~g}$ dry weight $\cdot \mathrm{m}^{-2}$. The $Z$. japonica at SLL relied on asexual and sexual reproduction to maintain the population. The results show the necessity of understanding local reproductive strategies before starting restoration and management projects. The study provides fundamental information and guidance for the conservation and restoration of seagrass beds.

Keywords: seagrass, asexual reproduction, sexual reproduction, seed bank, seedling 


\section{INTRODUCTION}

Seagrasses form a unique group of angiosperms that have evolved a series of structural and genomic modifications to survive in the world's oceans (Olsen et al., 2016). As important habitat-formers, seagrasses are the basis of one of the most productive and widespread coastal ecosystems worldwide (Costanza et al., 1997; Duffy, 2006; York et al., 2015). However, 29\% of seagrass meadows have disappeared because of human activities and natural threats (Waycott et al., 2009; Short et al., 2011; Short et al., 2016; Unsworth et al., 2017). Therefore, effective management programs and active restoration work are becoming increasingly important (Zhou et al., 2014; Unsworth et al., 2015; CullenUnsworth and Unsworth, 2016; van Katwijk et al., 2016; Lefcheck et al., 2017). Understanding their reproductive strategies is essential for the conservation, management, and restoration of seagrasses.

Seagrasses are submerged marine angiosperms capable of both sexual and asexual reproduction. It is usually assumed that the recruitment of seagrass populations occurs mainly through asexual reproduction (Williams, 1990; Procaccini and Mazzella, 1998; Rasheed, 2004). The recovery of gaps within seagrass meadows solely by asexual reproduction may be common. In a multi-species Caribbean seagrass meadow, all the recolonization occurred through vegetative propagation (Williams, 1990). Rasheed (1999) found that the recolonization of artificially cleared plots in a seagrass meadow dominated by Zostera capricorni occurred principally by asexual growth from surrounding rhizomes. A microsatellite markerbased study reported that clonal growth is important in the maintenance of Posidonia oceanica populations (Procaccini and Mazzella, 1998). Successful sexual recruitment is limited owing to low pollination rates, restricted pollen and seed dispersal, and low seed and seedling survival rates (Les, 1988; Laushman, 1993; Reusch, 2003). However, sexual reproduction is the only way to maintain the genetic diversity of a seagrass population (Ackerman, 2006; Reynolds et al., 2012, 2013). Sexual recruitment can provide a means for seagrasses to colonize new areas or to establish new patches of seagrasses (Rasheed, 2004; Kendrick et al., 2012). Under highly disturbed conditions, in which there is few remnant seagrass available, initial recolonization may occur by seeding (Marba and Walker, 1999; Greve et al., 2005; Lee et al., 2007).

The amounts of sexual and asexual reproduction differ within some species relying on geographic location and environmental conditions (Rasheed, 2004; Xu S.et al., 2018; Zhang et al., 2020b). Z. capricorni flowering occurs from September to April in Botany Bay, New South Wales (Larkum et al., 1984). However, there is only a low incidence of $Z$. capricorni flowering at Ellie Point (September and October), northern Queensland (McKenzie, 1994). The flowering duration is longer in the midshore zone (7 months), compared with the offshore (4 months), and inshore (3 months) zones (Conacher et al., 1994). Many local populations of $Z$. marina are maintained mainly by clonal growth from perennial rhizomes (Phillips,
1972; Tomlinson, 1974), while in other populations, annual seagrass is established each year from seeds (Felger and McRoy, 1975; Keddy and Patriquin, 1978; Bayer, 1979; Harrison, 1979).

Z. japonica is an intertidal seagrass species that is native to the Western Pacific Ocean from Russia to Vietnam (Miki, 1933), and has been successfully introduced to the coastlines of British Columbia (Canada), as well as Washington, Oregon, and northern California (United States) (Shafer et al., 2014). However, it is widely threatened by human disturbances in its native range of China, Korea, and Japan (Lee et al., 2004; Abe et al., 2009; Hodoki et al., 2013; Zhang et al., 2019, 2020a). Thus, conservation and restoration efforts are required urgently for $Z$. japonica in its native habitat.

Limited studies have been conducted on the reproductive strategy of Z. japonica. Henderson and Hacker (2015) investigated the reproductive allocation of $Z$. japonica under different sediment disturbance regimes. Flowering biomass was negatively correlated with vegetative biomass as the sediment disturbance increased. Suonan et al. (2017) showed that sexual reproductive effort in $Z$. japonica tends to be enhanced under disturbed (due to calm harvesting) and inundated environmental conditions for population persistence. Zhang et al. (2019) reported on the temporal and spatial changes in population recruitment in $Z$. japonica meadows located in the Yellow River Delta, China. The positive effects of Z. japonica's sexual reproduction on the population's genetic diversity was confirmed by a microsatellite analysis (Zhang et al., 2020b). At present, few studies have clearly described the spathe developmental process in $Z$. japonica. Additionally, understanding the differences in $Z$. japonica reproductive strategies at large spatial scales is essential for the conservation and management of this species.

Here, we studied the reproductive strategies of two different geographic populations of Z. japonica in northern China, Swan Lake (SLL) and Huiquan Bay (HQB). The winter at SLL is relatively cold, and on the coldest days the lagoon is covered with ice. In contrast, the winter at HQB is warmer, with a very low likelihood of snow and ice. Thus, at SLL, the Z. japonica meadow is almost bare in winter owing to the lower temperature, while Z. japonica survives the winter well at HQB. The aims of this study were as follows: (1) to compare the differences in reproductive strategies and determine the causes; and (2) to describe the spathe developmental process in $Z$. japonica. Our study will provide basic information to clarify the roles of sexual and asexual reproduction in population recruitment and to establish restoration and conservation strategies.

\section{MATERIALS AND METHODS}

\section{Study Sites}

The SSL (Figure 1; $122^{\circ} 34^{\prime} \mathrm{E}, 37^{\circ} 21^{\prime} \mathrm{N}$ ) is located east of Weihai City, northern China. It is $\sim 2.1 \mathrm{~km}$ long and $\sim 1.8$ $\mathrm{km}$ wide, covering an area of $\sim 4.8 \mathrm{~km}^{2}$ (Xu S.et al., 2018). The lagoon has irregular semidiurnal mixed tides (tidal 


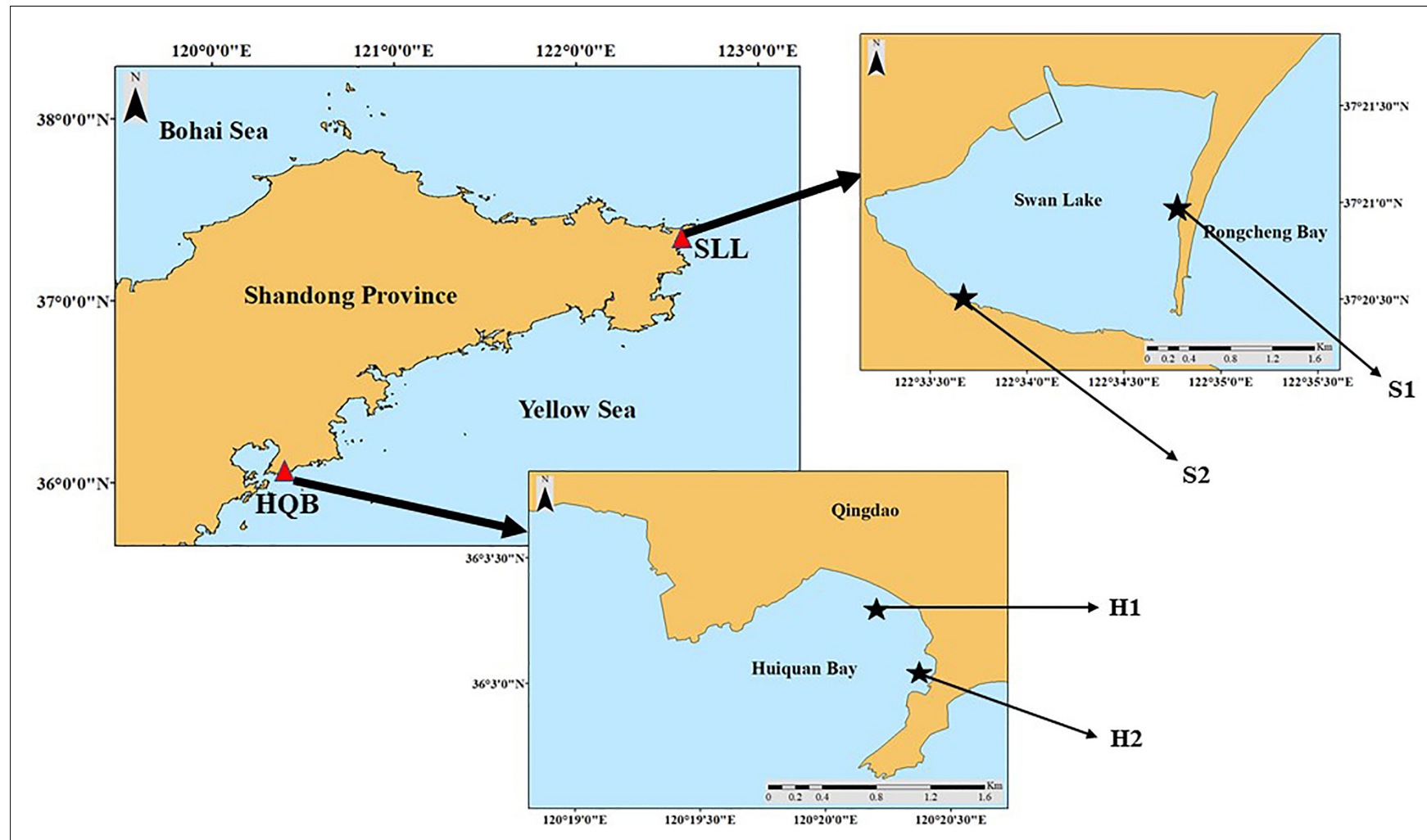

FIGURE 1 | Zostera japonica study sites in Swan Lake (SLL) and Huiquan Bay (HQB).

range $=1.65 \mathrm{~m}$ ) (Zhang et al., 2020b). The lagoon is shallow (average depth $<1.5 \mathrm{~m}$ ) and is colonized by $Z$. marina and Z. japonica (Zhang et al., 2014, 2015; Zhou et al., 2015; Xu Q.et al., 2018; Xu et al., 2019). Z. japonica principally occurs in the narrow mid-upper intertidal zone, which is divided into two parts (Zhang et al., 2015). Thus, two study sites were designed based on Z. japonica's spatial distribution. The sediment of S1 is mainly sandy, whereas the sediment of S2 is mainly mud.

The HQB (Figure 1; $120^{\circ} 34^{\prime} \mathrm{E}, 36^{\circ} 05^{\prime} \mathrm{N}$ ) is an open bay in Qingdao, northern China (Zhou et al., 2014). It has regular semidiurnal tides (tidal range $=4.8 \mathrm{~m}$ ). The sediment of the bay is mainly sandy and two seagrass species ( $Z$. marina and $Z$. japonica) colonize the southeastern corner of this bay (Xu S.et al., 2018). We surveyed two study sites based on the spatial distribution of $Z$. japonica (Figure 1). H1 was located in a noncontinuous $Z$. japonica patch area, while $\mathrm{H} 2$ was located in the species' continuous area.

\section{Environmental Parameters}

A HOBO Pendant light/temp MX 2202 (ONSET, United States) was used to record water temperatures $\left({ }^{\circ} \mathrm{C}\right)$ at SLL (S1 and S2) and HQB at 15-min interval from June 2018 to June 2019. The average daily values of the water temperatures were calculated, and the daily temperatures were averaged monthly. An ECOPARSB sensor (Sea-Bird Scientific, United States) deployed in the center of the $Z$. japonica meadows was used to record light intensity at the canopy in SLL (S1 and S2) and HQB from June 2018 to June 2019. Instantaneous photosynthetic photon flux densities (PPFDs; mol photons $\cdot \mathrm{m}^{-2} \cdot \mathrm{s}^{-1}$ ) were measured every $15 \mathrm{~min}$ and daily PPFDs ( $\mathrm{mol}$ photons $\cdot \mathrm{m}^{-2}$ - $\mathrm{d}^{-1}$ ) were calculated as the sum of the quantum flux within a $24 \mathrm{~h}$ period. Three sediment cores (diameter $=10.5 \mathrm{~cm}$ and depth $=12 \mathrm{~cm}$ ) were collected at each site for the determination of the grain size distribution using a laser diffraction analysis (Short and Coles, 2001).

\section{Biological Measurements}

During the flowering periods in 2018, seven replicate sediment cores (diameter $=10.5 \mathrm{~cm}$ and depth $=12 \mathrm{~cm}$ ) were collected semimonthly at the four sites. To investigate seedling recruitment, seven replicate sediment cores (diameter $=10.5 \mathrm{~cm}$ and depth $=12 \mathrm{~cm}$ ) were collected semimonthly from March to May in 2019 at all the sites. From June to December 2019, seven replicate sediment cores (diameter $=10.5 \mathrm{~cm}$ and depth $=12 \mathrm{~cm}$ ) were collected monthly at the four sites.

All the samples were sieved $(2 \mathrm{~mm})$ with seawater in situ to remove most of the sediment, and the seagrass materials were taken to the laboratory and cleaned using tap water. For each sample, the total number of shoots (including reproductive and vegetative shoots) was recorded to provide shoot density (shoots $\cdot \mathrm{m}^{-2}$ ). Next, they were dried to a constant weight at $60^{\circ} \mathrm{C}$ to estimate total shoot biomass $\left[\mathrm{g}\right.$ dry weight $(\mathrm{DW}) \cdot \mathrm{m}^{-2}$ ].

During the flowering periods, reproductive shoots and their seed production were investigated using the same cores described 
A
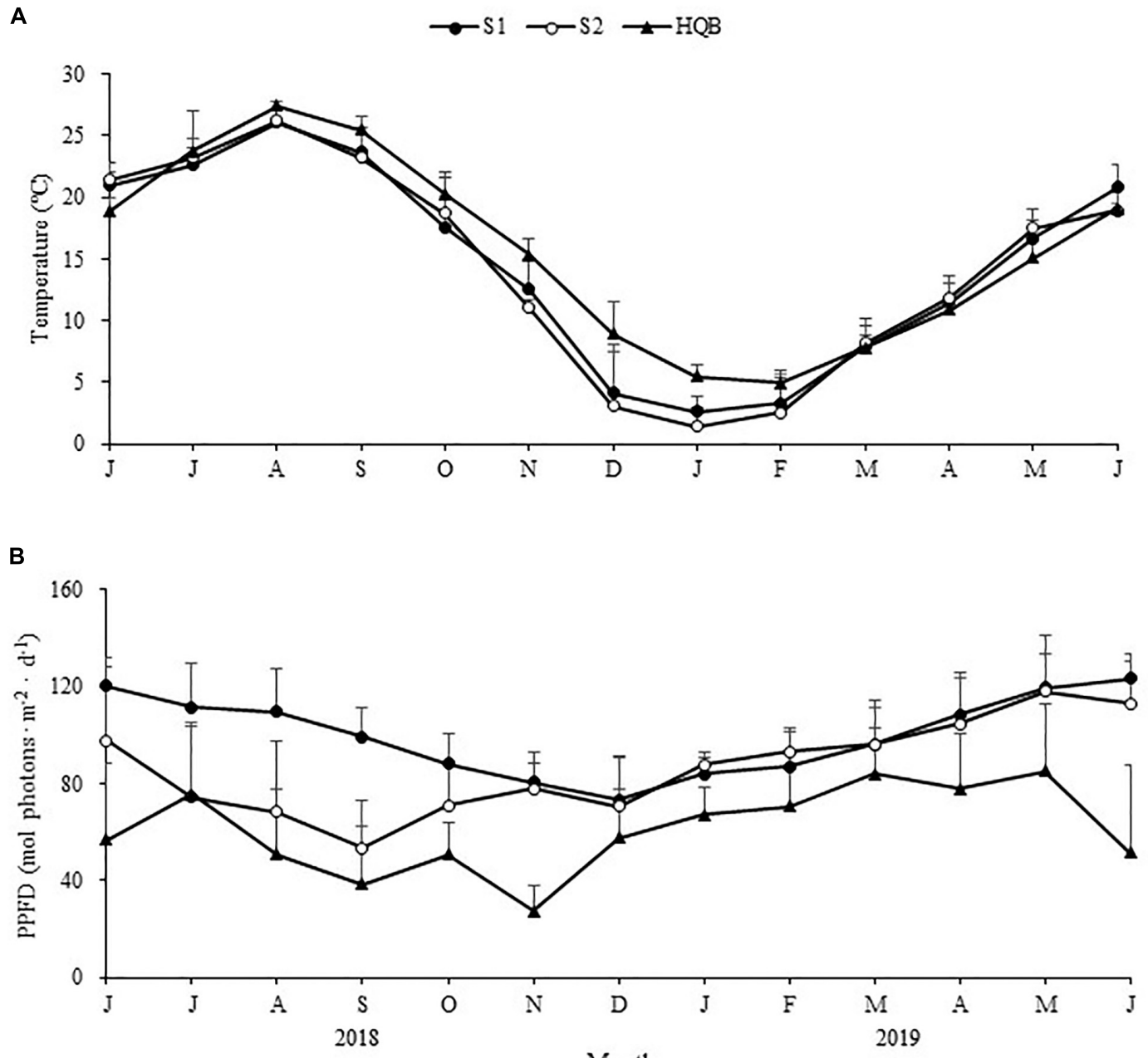

FIGURE 2 | Seasonal changes in temperature (A) and light intensity (B) in the study sites from June 2018 to June 2019 (Huiquan Bay is represented by H1 and H2). Values are mean $\pm S D$.

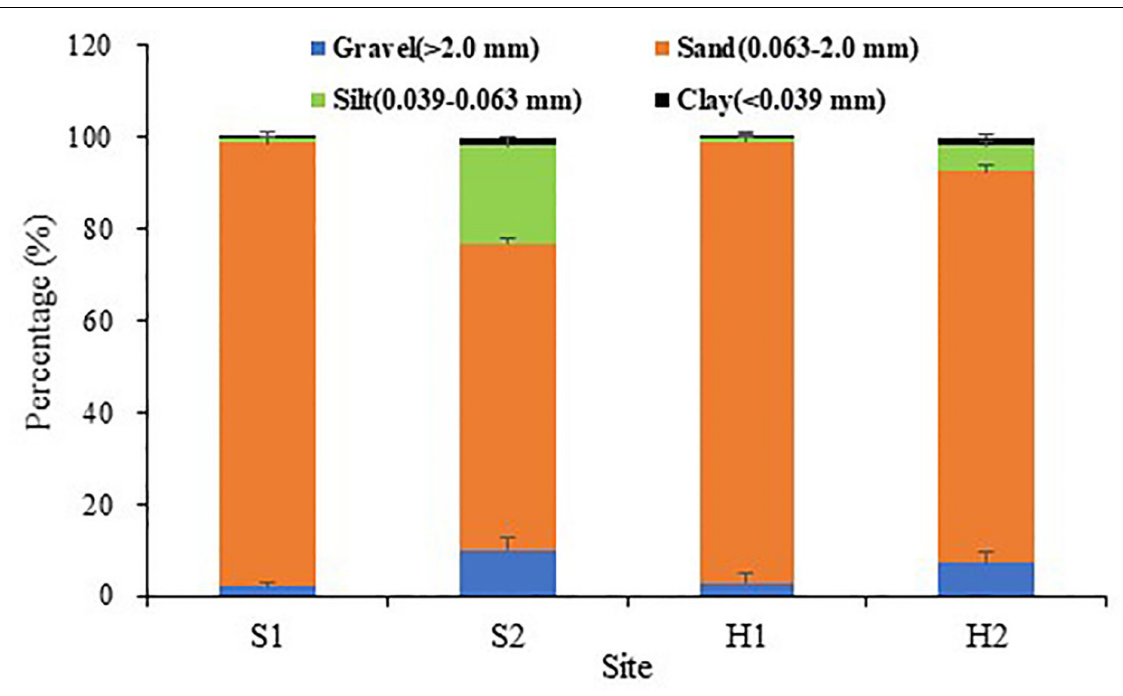

FIGURE 3 | Sediment grain sizes at the four study sites. Values are mean $\pm \mathrm{SD}(N=3$ cores per site). 
above. For each core, the reproductive shoot density (shoots - $\mathrm{m}^{-2}$ ) and the height of reproductive shoot $(\mathrm{cm})$ were determined. Flowering frequency (\%) was determined as the percentage of reproductive shoot density to total shoot density. The reproductive effort (\%) was calculated as the percentage of reproductive shoot biomass to total shoot biomass. For each reproductive shoot, the number of seed spathes per shoot and the number of spathes per shoot were counted. Spathes in which seed development had initiated ("seed spathes") were distinguished from those that contained flowers. For each spathe, the number of female flowers per flowering spathe or the number of seeds per seed spathe were counted. The potential seed production per unit area ( $P S P$, seeds $\cdot \mathrm{m}^{-2}$ ) in each core was calculated using the following equation:

$$
P S P_{i j k}=\bar{N}_{i j a} \times \bar{N}_{i} \times R S D_{i j k}
$$

i: study site ( 1 or $\mathrm{S} 2$ or $\mathrm{H} 1$ or $\mathrm{H} 2)$,

j: sampling time,

$\mathrm{k}$ : core serial number $(1-7)$,
$\bar{N}_{i j a}$ : the average number of spathes per shoot in sampling time $j$ at site $i$,

$\bar{N}_{i}$ : the average number of seeds per seed spathe at site $i$,

$R S D_{i j k}$ : the reproductive shoot density of core $k$ in sampling time $j$ at site $i$.

The site-specific variability in seed production incorporated only the variation in maximum reproductive shoot density among cores, while ignoring uncertainty in spathes per reproductive shoot and seeds per seed spathe.

Seedling recruitment was investigated using the same cores described above. For each core, the seedling density (shoots $\cdot \mathrm{m}^{-2}$ ) was determined, and seedling frequency was calculated as the ratio of seedlings to total shoots (\%).

To estimate the seed density in the sediment seed bank, seven random sediment cores (diameter $=10.5 \mathrm{~cm}$ and depth $=12 \mathrm{~cm}$ ) were collected monthly from March 2019 to December 2019 at each site. The sediment cores were sieved twice using 2 and $0.7 \mathrm{~mm}$ and mesh. Larger plant matter and other detritus were retained in the $2 \mathrm{~mm}$ mesh, while seeds mixed with small detritus were retained
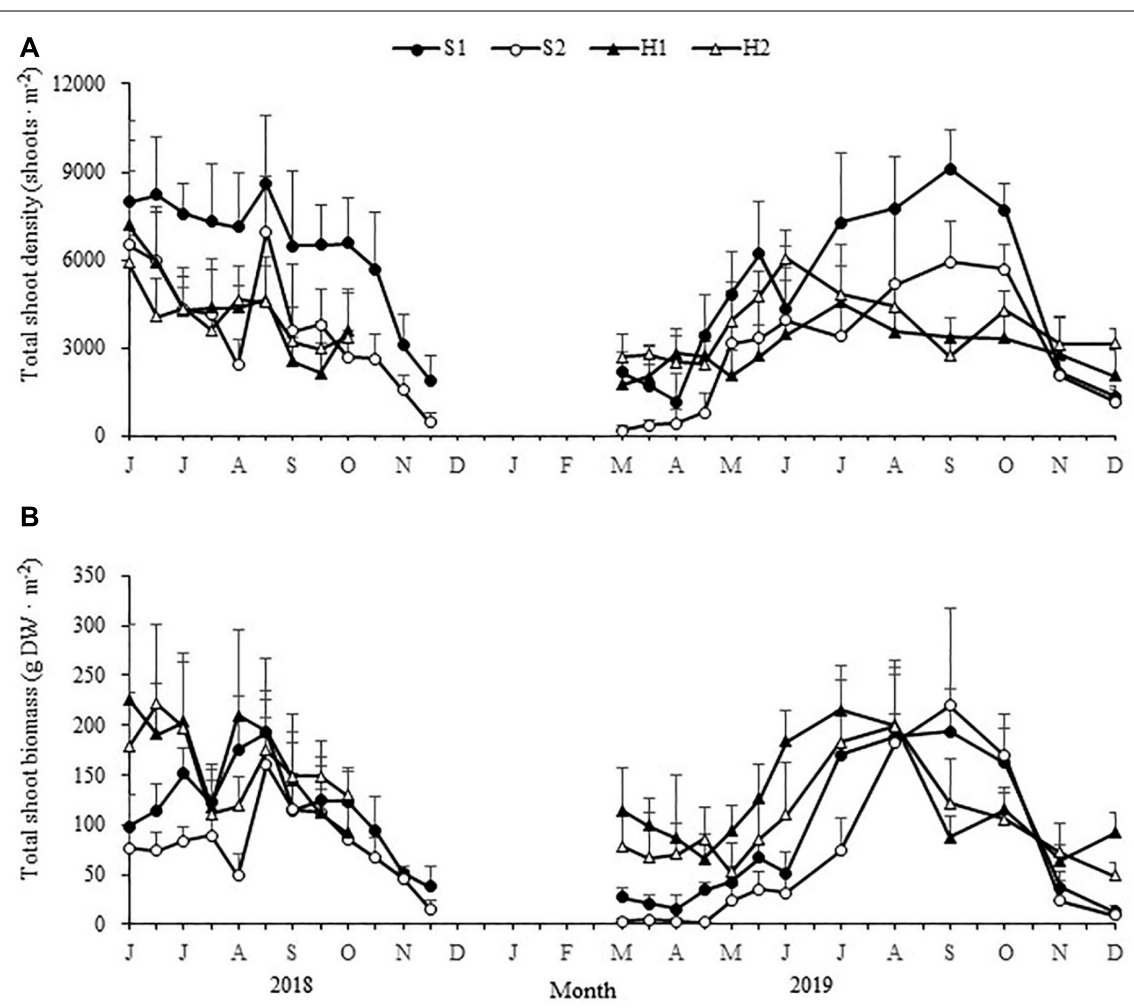

FIGURE 4 | Seasonal changes in total shoot densities (A) and biomasses (B) of Zostera japonica at the four study sites from June 2018 to December 2019 . Values are mean $\pm S D(N=7$ cores per site).

TABLE 1 | The total shoot density and biomass of Zostera japonica among the four study sites at the beginning of spring (2019.3.15).

\begin{tabular}{|c|c|c|c|c|}
\hline Variable & S1 & S2 & H1 & $\mathrm{H} 2$ \\
\hline Total shoot density (shoots $\cdot \mathrm{m}^{-2}$ ) & $2162.35 \pm 717.60^{a b}$ & $165.06 \pm 186.99^{c}$ & $1733.18 \pm 411.23^{b}$ & $2674.05 \pm 773.46^{a}$ \\
\hline Total shoot biomass (g DW $\cdot \mathrm{m}^{-2}$ ) & $27.57 \pm 8.48^{C}$ & $2.64 \pm 3.70^{c}$ & $114.39 \pm 42.82^{a}$ & $78.41 \pm 29.69^{b}$ \\
\hline
\end{tabular}

Different letters indicate significant differences at $p<0.05$. Values are mean $\pm S D(N=7$ cores per site). 
in the $0.7 \mathrm{~mm}$ mesh. The number of viable seeds with hard pericarps was recorded to calculate seed bank density ( seeds $\cdot \mathrm{m}^{-2}$ ).

\section{Data Analysis}

The significance levels of the differences in total shoot density and biomass among the sampling times and the four sites were tested using a two-way ANOVA. A one-way ANOVA was used to test the significance of differences in the maximum height of reproductive shoots, maximum reproductive shoot density, maximum flowering frequency, maximum reproductive effort, maximum number of spathes per reproductive shoot, maximum number of seed spathes per reproductive shoot, maximum number of female flowers per flowering spathe, maximum number of seeds per seed spathe, maximum potential seed production, maximum seed density in sediment, maximum seedling density and maximum seedling frequency among the four sites. When these data did not satisfy the homogeneity of variance, a Kruskal-Wallis Test was used to test the significances of differences. Multiple comparisons were performed using the Duncan method or Independent-Samples $T$-tests, and the level of significance was set at $p<0.05$. Statistical analyses
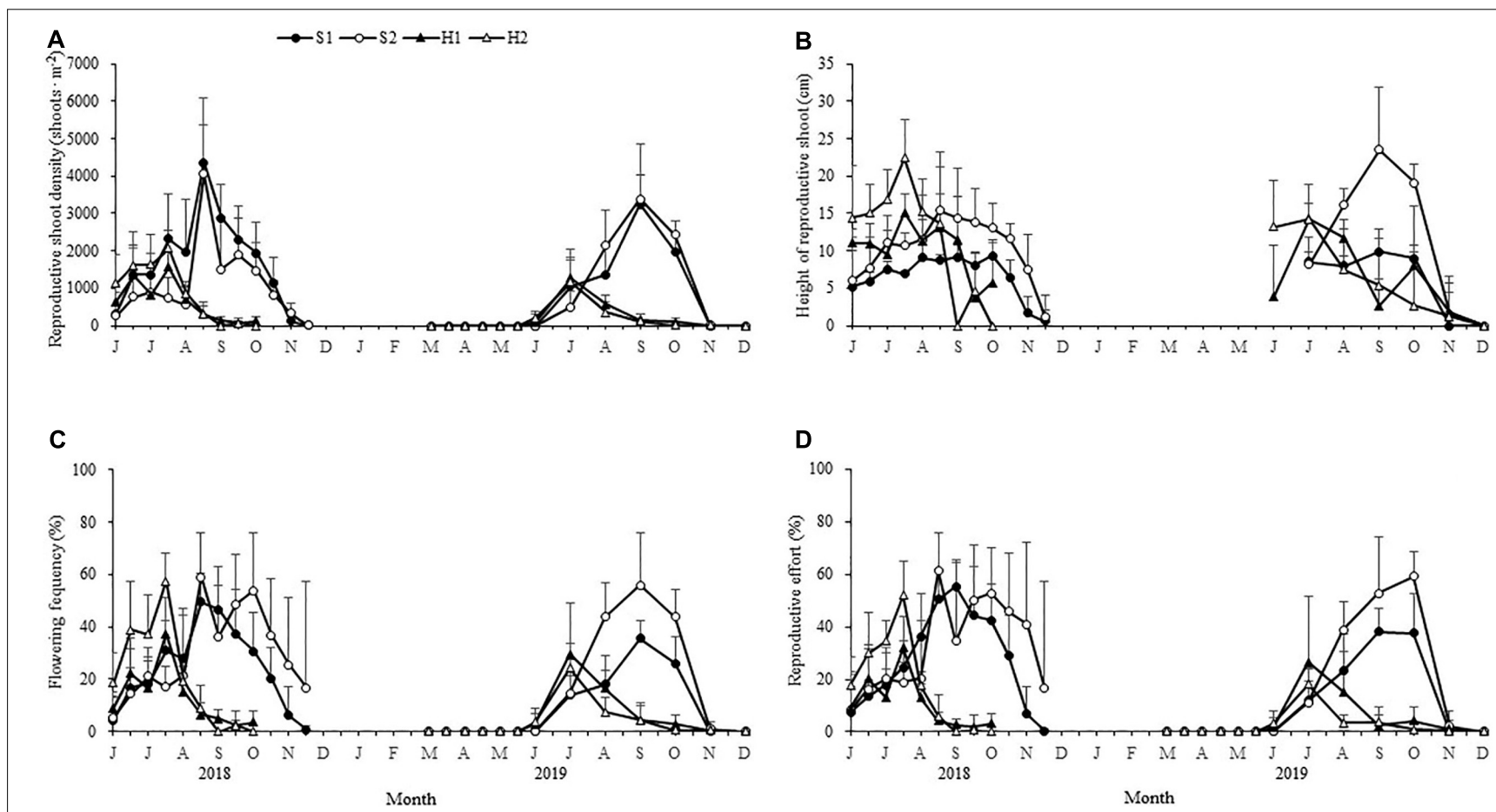

FIGURE 5 | Seasonal changes in the reproductive shoot densities (A), reproductive shoot height (B), flowering frequency (C), and reproductive effort (D) of Zostera japonica at the four study sites from June 2018 to December 2019. Values are mean \pm SD $(N=7$ cores per site).

TABLE 2 | Flowering traits of Zostera japonica at the four study sites from June 2018 to December 2019.

$\begin{array}{lllll}\text { Variable } & \mathrm{S1} & \mathrm{S} 2 & \mathrm{H} & \mathrm{H}\end{array}$

Maximum reproductive shoot density (shoots $\cdot \mathrm{m}^{-2}$ )

Maximum flowering frequency (\%)

Maximum reproductive effort (\%)

Maximum height of reproductive

shoots (cm)

Maximum number of spathes per reproductive shoot

Maximum number of seed spathes per reproductive shoot

Maximum number of female flowers per flowering spathe

Maximum number of seeds per seed spathe
$4357.70 \pm 1731.53^{a}(2018.8 .30) 4060.59 \pm 1299.44^{a}(2018.8 .30) 1568.11 \pm 711.82^{b}(2018.7 .30) 2063.31 \pm 492.16^{b}(2018.7 .30)$
$55.31 \pm 10.26^{a}(2018.9 .15)$

$9.85 \pm 1.83^{b}(2019.9 .15)$

$2.66 \pm 0.40^{b}(2018.9 .30)$

$2.24 \pm 0.40^{b}(2019.10 .15)$

$5.85 \pm 0.40(2019.7 .15)$

$3.73 \pm 1.03^{a b}(2018.8 .15)$
$59.03 \pm 16.58^{a}(2018.8 .30)$

$61.15 \pm 14.57^{a}(2018.8 .30)$

$23.49 \pm 8.37^{a}(2019.9 .15)$

$3.41 \pm 0.48^{a}(2019.10 .15)$

$2.75 \pm 0.50^{a}(2019.10 .15)$

$5.95 \pm 0.49(2018.8 .30)$

$4.55 \pm 0.48^{a}(2019.9 .15)$
$37.29 \pm 13.58^{b}(2018.7 .30)$

$31.96 \pm 11.97^{b}(2018.7 .30)$

$15.09 \pm 2.59^{b}(2018.7 .30)$

$2.15 \pm 0.28^{b}(2019.8 .15)$

$1.25 \pm 0.34^{d}(2019.8 .15)$

$3.81 \pm 2.76(2018.6 .30)$

$2.70 \pm 1.62^{C}(2019.7 .15)$
$57.45 \pm 10.55^{a}(2018.7 .30)$

$51.90 \pm 13.24^{a}(2018.7 .30)$

$22.46 \pm 4.98^{a}(2018.7 .30)$

$2.45 \pm 0.66^{b}(2018.7 .30)$

$1.75 \pm 0.39^{C}(2018.7 .30)$

$5.99 \pm 1.07(2018.7 .15)$
$3.88 \pm 0.67^{a b}(2018.7 .30)$

Different letters indicate significant differences at $p<0.05$. Values are mean $\pm S D(N=7$ cores per site). 
were conducted using SPSS 17.0. All values are reported as mean $\pm \mathrm{SD}$.

Any data collected at the shoot level (i.e., reproductive shoot height and number of spathes per reproductive shoot), as well as data collected at the spathe level (i.e., seeds per seed spathe) were first averaged to generate core-specific numbers. Thus, a core was the sample in all the statistical tests and in calculations of mean and SD. For maximumvalue trait comparisons, data were used from different dates across sites, if maximum values were reached on different dates.

\section{RESULTS}

\section{Environmental Parameters}

Winter was relatively colder at SLL, and ice formed on the water surface on the coldest days. By comparison, the winter was warmer at $\mathrm{HQB}$, with extremely low probabilities of snow and ice (Figure 2A). The water temperature averaged $3.37 \pm 2.81^{\circ} \mathrm{C}$ at $\mathrm{S} 1,2.34 \pm 3.24^{\circ} \mathrm{C}$ at $\mathrm{S} 2$, and $6.53 \pm 2.42^{\circ} \mathrm{C}$ at $\mathrm{HQB}$ in winter. The annual maximum temperature was highest at HQB $\left(28.23^{\circ} \mathrm{C}\right)$, and the annual minimum temperature was lowest at $\mathrm{S} 2\left(-4.56^{\circ} \mathrm{C}\right)$. The negative accumulated temperature was $-14.60^{\circ} \mathrm{C}$ at $\mathrm{S} 1,-37.46^{\circ} \mathrm{C}$ at $\mathrm{S} 2$, and $0^{\circ} \mathrm{C}$ at $\mathrm{HQB}$. The light increased in spring and summer and decreased in fall and winter at all the study sites (Figure 2B). The sediment particulate size composition at each site is shown in Figure 3. The sediments at all the sites were mainly composed of sand $(0.063-2.0 \mathrm{~mm})$, whereas the proportion of silt $(0.039-0.063 \mathrm{~mm})$ at S2 $(21.55 \pm 1.60 \%)$ was greater than at the other sites.

\section{Temporal Changes in the Density and Biomass of $Z$. japonica}

There were significant site $\times$ time interactions for total shoot density and biomass $\left[F_{(66,555)}=4.981, p<0.05 ; F_{(66,555)}=5.170\right.$,

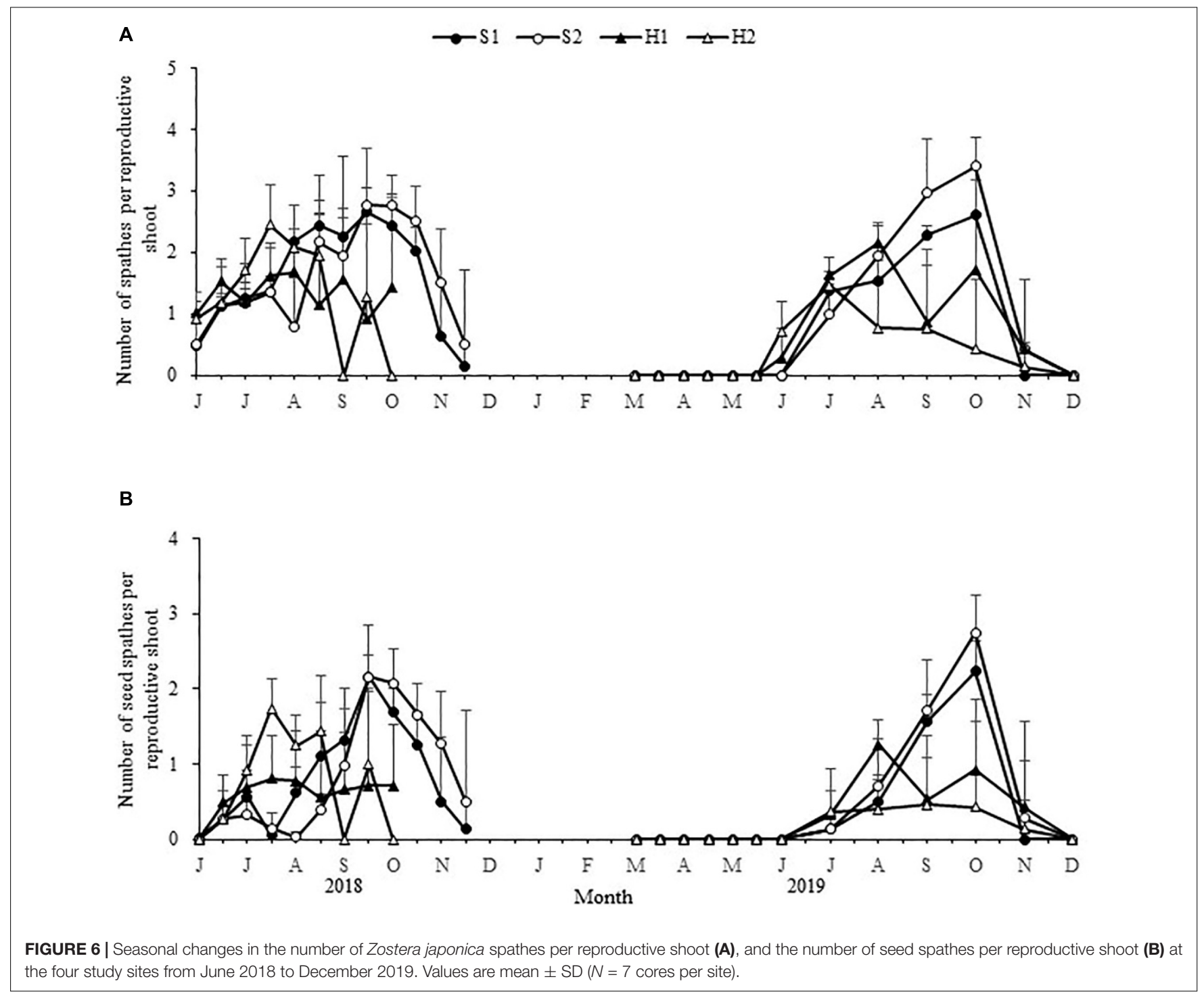


$p<0.05$, respectively]. At the beginning of spring (early March), the total shoot density was greatest at $\mathrm{H} 2$, followed by $\mathrm{S} 1, \mathrm{H} 1$, and S2 $\left[F_{(3,24)}=24.930, p<0.05\right.$; Figure 4 and Table 1]; and the total shoot biomass was greatest at $\mathrm{H} 1(114.39 \pm 42.82 \mathrm{~g}$ $\left.\mathrm{DW} \cdot \mathrm{m}^{-2}\right)$, followed by $\mathrm{H} 2\left(78.41 \pm 29.69 \mathrm{~g} \mathrm{DW} \cdot \mathrm{m}^{-2}\right)$, $\mathrm{S} 1\left(27.57 \pm 8.48 \mathrm{~g} \mathrm{DW} \cdot \mathrm{m}^{-2}\right)$, and $\mathrm{S} 2[2.64 \pm 3.70 \mathrm{~g}$ $\mathrm{DW} \cdot \mathrm{m}^{-2}$; Chi-square $(3)=23.499, p<0.05$; Figure 4 and Table 1].

\section{Flowering Characteristics}

At SLL, reproductive shoots were observed first in June, and they lasted until November in 2018, while the reproductive shoots at HQB were observed from June to October in 2018. The flowering duration at SLL was longer than at HQB.

The maximum reproductive shoot density at SLL was greater than at HQB $\left[F_{(3,24)}=10.123, p<0.05\right.$; Figure 5A and Table 2]. The maximum height of reproductive shoots varied significantly [Chi-square $_{(3)}=19.087, p<0.05$ ] among the four study sites (Figure 5B). The maximum height of reproductive shoots at $\mathrm{S} 1(9.85 \pm 1.83 \mathrm{~cm})$ was lower than at other sites (Table 2). The flowering frequency at SLL was greatest in August during $2018(49.32 \% \pm 11.02 \%$ at $\mathrm{S} 1$ and $59.03 \% \pm 16.58 \%$ at S2) and in September during 2019 (35.49\% $\pm 6.62 \%$ at $\mathrm{S} 1$ and $55.77 \% \pm 20.33 \%$ at $\mathrm{S} 2$, Figure 5C). At HQB, the flowering frequencies were greatest in July during 2018 $(37.29 \% \pm 13.58 \%$ at $\mathrm{H} 1$ and $57.45 \% \pm 10.55 \%$ at $\mathrm{H} 2)$ and $2019(29.62 \% \pm 19.47 \%$ at $\mathrm{H} 1$ and $24.26 \% \pm 9.14 \%$ at $\mathrm{H} 2$ ). Therefore, the maximum flowering frequency at S2 was greater than those at other sites $\left[F_{(3,24)}=4.003, p<0.05\right.$; Table 2].

The reproductive effort at S1 was greatest in September during $2018(55.31 \% \pm 10.26 \%)$ and 2019 (38.08\% \pm 8.99\%). At S2, the reproductive effort was greatest in August during 2018 $(61.15 \% \pm 14.57 \%)$ and October during $2019(59.07 \% \pm 9.32 \%)$. At $\mathrm{HQB}$, the reproductive effort was greatest in July during $2018(31.96 \% \pm 11.97 \%$ at $\mathrm{H} 1$ and $26.46 \% \pm 25.10$ at $\mathrm{H} 2)$ and $2019(51.90 \% \pm 13.24 \%$ at $\mathrm{H} 1$ and $17.98 \% \pm 5.77 \%$ at $\mathrm{H} 2)$. Therefore, the maximum reproductive effort at S2 was greater than those at other sites $\left[F_{(3,24)}=7.065, p<0.05\right.$; Figure 5D and Table 2].

The maximum number of spathes per reproductive shoot and the maximum number of seed spathes per

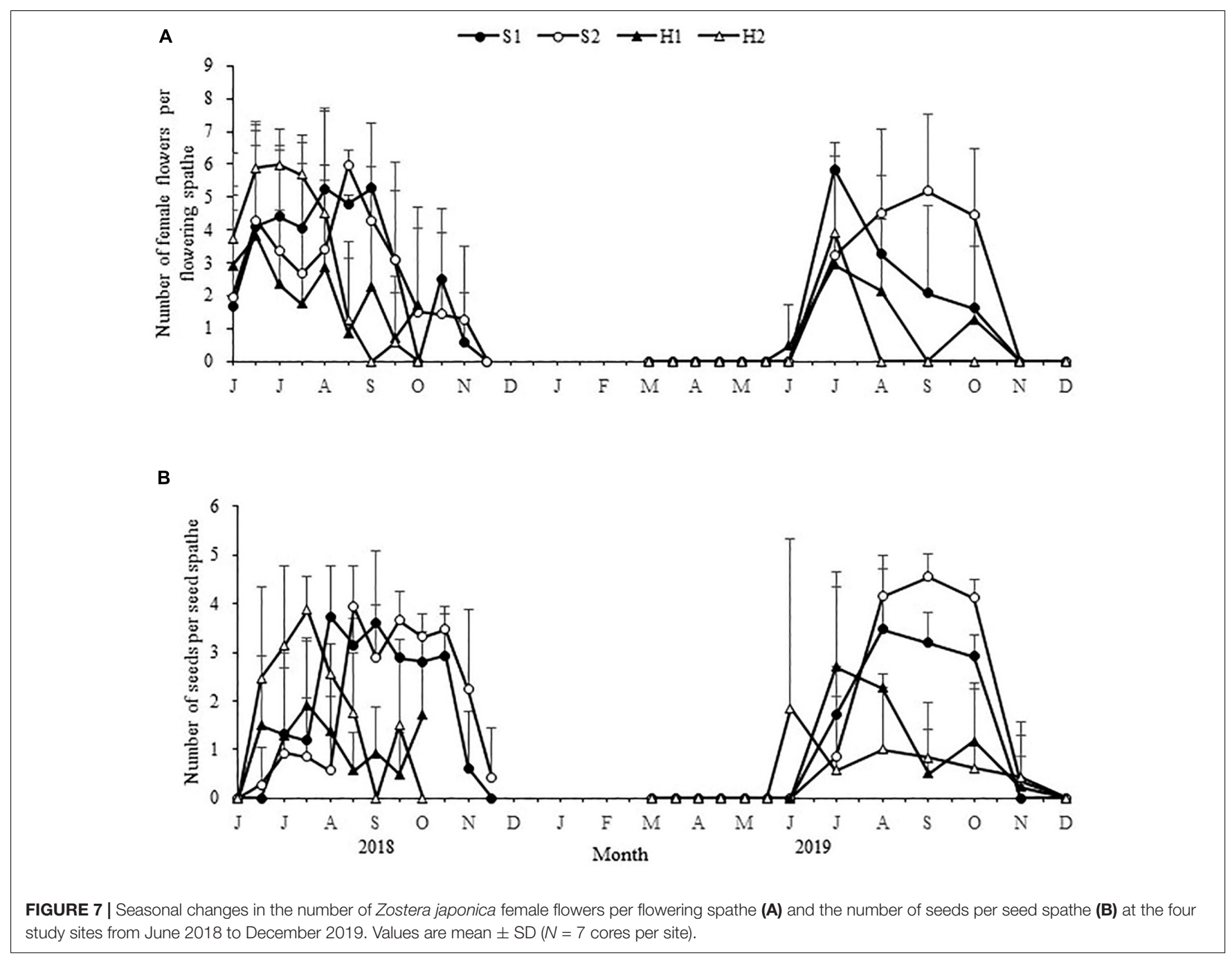


reproductive shoot were significantly different among the four study sites $\left[F_{(3,24)}=8.931, p<0.05 ; F_{(3}\right.$, $24)=16.994, p<0.05$, respectively; Figure 6]. The values at S2 $(3.41 \pm 0.48 ; 2.75 \pm 0.50$, respectively) were higher than at S1 $(2.66 \pm 0.40 ; 2.24 \pm 0.40$, respectively), $\mathrm{H} 2$ (2.45 \pm 0.66 ; $1.75 \pm 0.39$, respectively), and $\mathrm{H} 1$ (2.15 $\pm 0.28 ; 1.25 \pm 0.34$, respectively) (Table 2 ).

There were no significant differences in the maximum number of female flowers per flowering spathe among the four study sites [Chi-square $_{(3)}=6.354, p>0.05$; Figure 7A]. The maximum number of seeds per seed spathe varied significantly among the four study sites [Chi-square $(3)=7.984, p<0.05$; Figure 7B]. The value was highest at S2 (4.55 \pm 0.48$)$, followed by $\mathrm{H} 2$ $(3.88 \pm 0.67), \mathrm{S} 1(3.73 \pm 1.03)$, and $\mathrm{H} 1(2.70 \pm 1.62)$ (Table 2). Based on a large number of observations, we recorded the spathe developmental process and the morphology of female and male flowers (Figure 8).

\section{Potential Seed Production, Seed Density in Sediment and Seedling Data}

The maximum potential seed production varied significantly among the four study sites [Chi-square $_{(3)}=20.390, p<0.05$; Figure 9A]. The value was highest at $S 1$ (22228.52 \pm 8832.46 seeds $\left.\cdot \mathrm{m}^{-2}\right)$, followed by S2 $\left(21630.34 \pm 9378.67\right.$ seeds $\left.\cdot \mathrm{m}^{-2}\right)$, $\mathrm{H} 2\left(7459.60 \pm 1779.33\right.$ seeds $\left.\cdot \mathrm{m}^{-2}\right)$, and $\mathrm{H} 1(2821.05 \pm 1280.57$ seeds $\cdot \mathrm{m}^{-2}$ ) (Table 3 ).

The maximum seed density in sediment at S2 $\left(2954.65 \pm 2549.72\right.$ seeds $\left.\cdot \mathrm{m}^{-2}\right)$ was higher than those at other sites [Chi-square $(3)=18.049, p<0.05$; Figure 9B and Table 3].

The maximum seedling density and frequency varied significantly among the four study sites [Chi-square $(3)=17.709$, $p<0.05$; Chi-square $(3)=13.478, p<0.05$, respectively; Figure 10].The maximum seedling density and frequency at S2 were $1,254.49 \pm 1,490.83$ shoots $\cdot \mathrm{m}^{-2}$ and $30.90 \% \pm 30.15 \%$, respectively. The maximum seedling density and frequency at S1 were $82.53 \pm 114.26$ shoots $\cdot \mathrm{m}^{-2}$ and $3.83 \% \pm 5.79 \%$, respectively. At SLL, seedlings were observed first in early April, were most prevalent in early May and lasted until June (Figure 10). No seedlings were found in situ at HQB.

\section{DISCUSSION}

In this study, we report the differences in reproductive strategies of $Z$. japonica under different geographic and environmental conditions in northern China. The seasonal changes in total shoot density and biomass were small in HQB. There was a relatively large number of overwintering shoots at HQB because of the higher average temperature in winter. The allocation to sexual reproduction was lower than at SLL, and no seedlings were observed at HQB during our study. Thus, the population of $Z$. japonica at HQB was maintained by asexual reproduction. Compared with HQB, the biomass of overwintering shoots at SLL was less than $30 \mathrm{~g}$ DW $\cdot \mathrm{m}^{-2}$. The $Z$. japonica

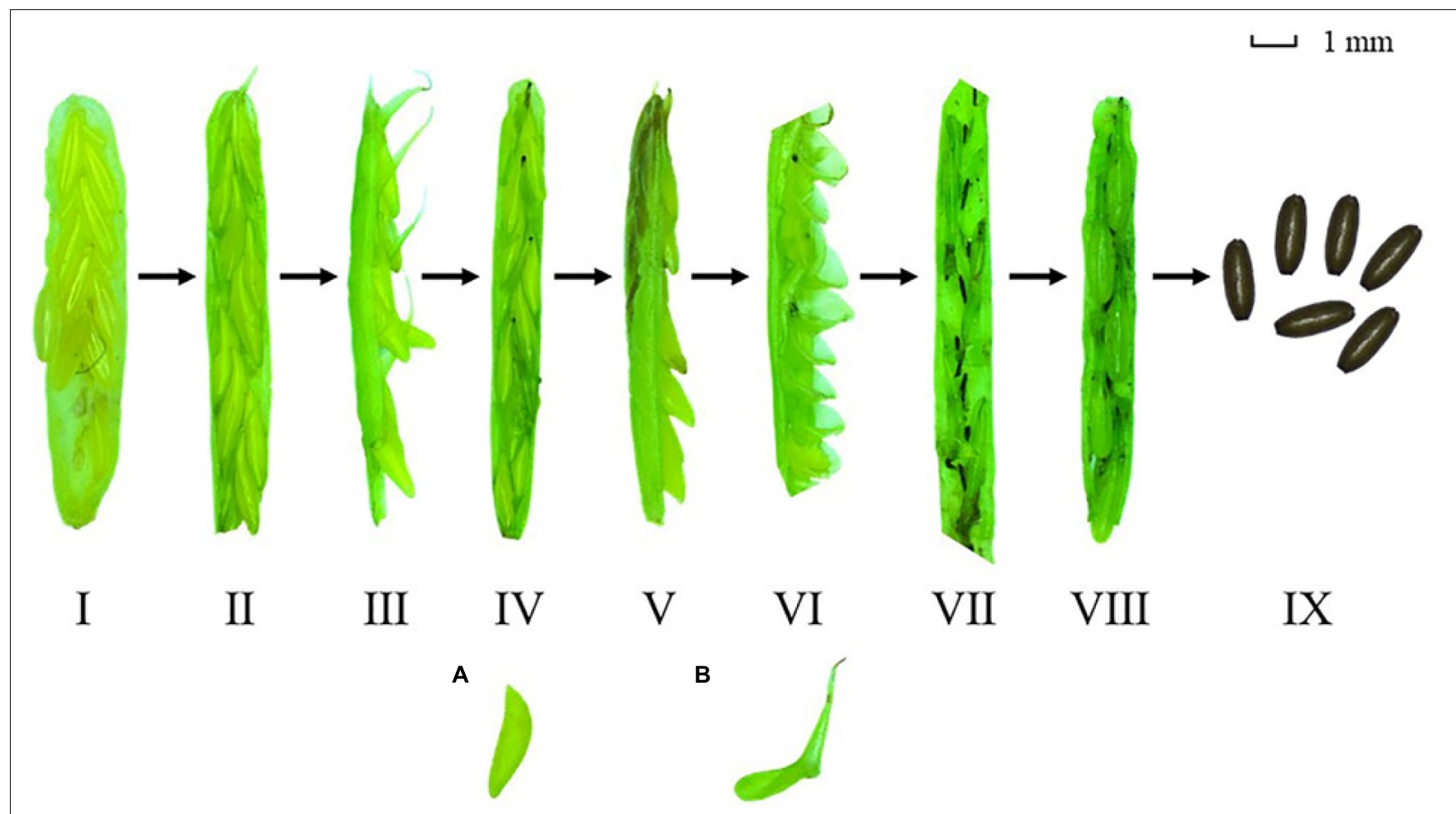

FIGURE $\mathbf{8}$ | The Zostera japonica spathe developmental process and the morphology of male (A) and female (B) flowers. 


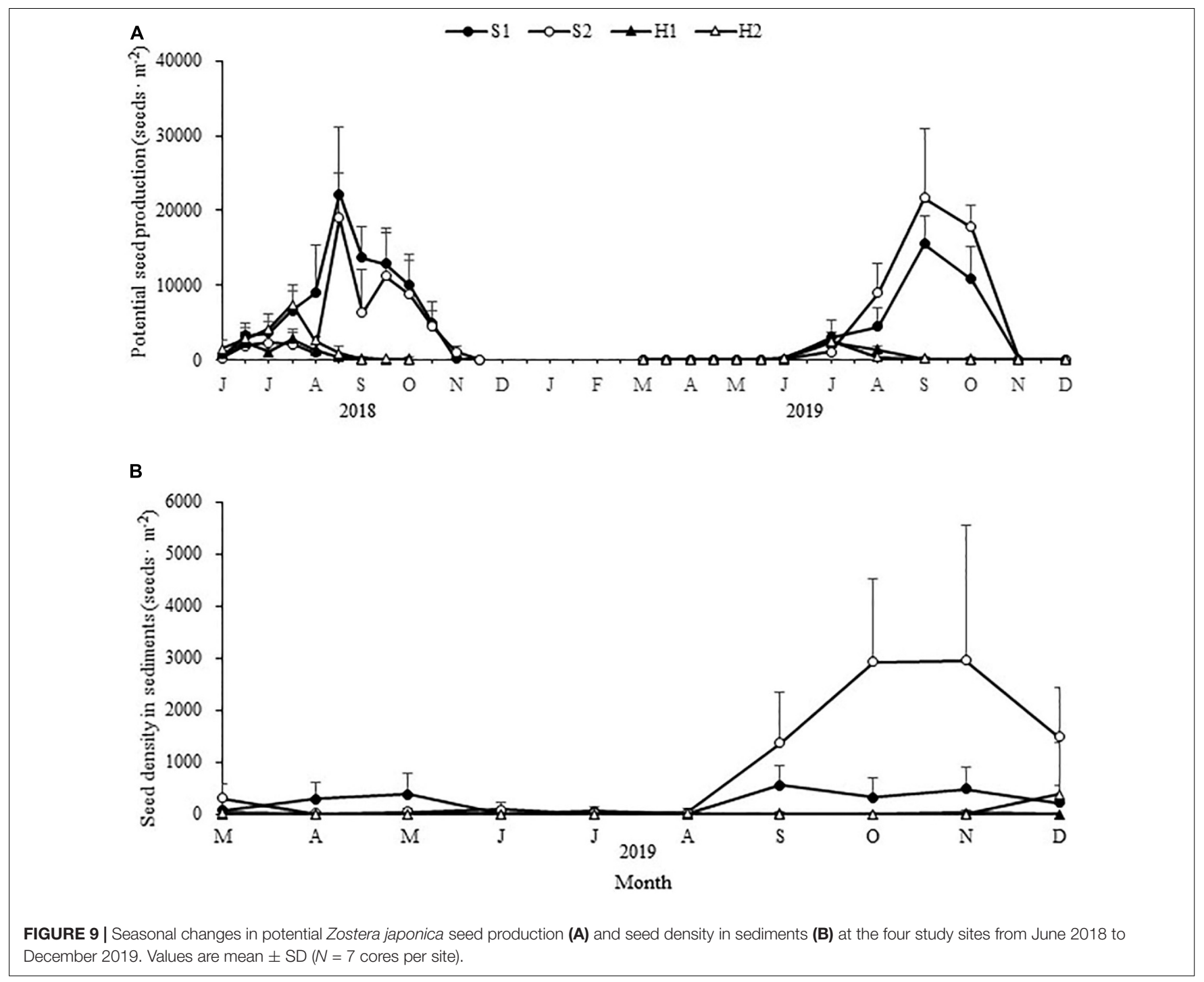

TABLE 3 | Maximum potential seed production and maximum seed density in sediment of Zostera japonica at the four study sites from March 2019 to December 2019.

\begin{tabular}{|c|c|c|c|c|}
\hline Variable & S1 & S2 & H1 & $\mathrm{H} 2$ \\
\hline $\begin{array}{l}\text { Maximum potential } \\
\text { seed production } \\
\left(\text { seeds } \cdot \mathrm{m}^{-2} \text { ) }\right.\end{array}$ & $22228.52 \pm 8832.46^{a}(2018.8 .30)$ & $21630.34 \pm 9378.67^{a}(2019.9 .15)$ & $2821.05 \pm 1280.57^{b}(2018.7 .30)$ & $7459.60 \pm 1779.33^{b}(2018.7 .30)$ \\
\hline $\begin{array}{l}\text { Maximum seed } \\
\text { density in sediment } \\
\text { (seeds } \cdot \mathrm{m}^{-2} \text { ) }\end{array}$ & $561.22 \pm 367.99^{b}(2019.9 .15)$ & $2954.65 \pm 2549.72^{a}(2019.11 .15)$ & $33.01 \pm 56.38^{b}(2019.11 .15)$ & $379.65 \pm 1004.46^{b}(2019.12 .15)$ \\
\hline
\end{tabular}

Different letters indicate significant differences at $p<0.05$. Values are mean $\pm S D(N=7$ cores per site).

of SLL relied on asexual and sexual reproduction to maintain its population.

Zhang et al. (2019) reported that $Z$. japonica located in the Yellow River Delta mainly relied on seedlings for population maintenance owing to the low temperature in winter. In spring, there were more germinated seeds of $Z$. marina in the area where ice had removed the aboveground tissue of $Z$. marina on its meadows (Robertson and Mann, 1984). This phenomenon is similar to the seedling recruitment of $Z$. japonica at SLL.
The flowering frequency at $\mathrm{H} 2$ was nearly $20 \%$, while the flowering frequencies at S1 and S2 were both less than $6 \%$ in the mid June 2018. Thus, the flowering initiation at HQB might have occurred before mid June 2018. In 2019, reproductive shoots were recorded in the early June at HQB (Figure 5B). Thus, the flowering initiation may occur earlier at HQB than at SLL, while the flowering duration at SLL was longer than at HQB (Figure 5A). In addition, the timing of seed maturation at HQB was earlier than at SLL. 

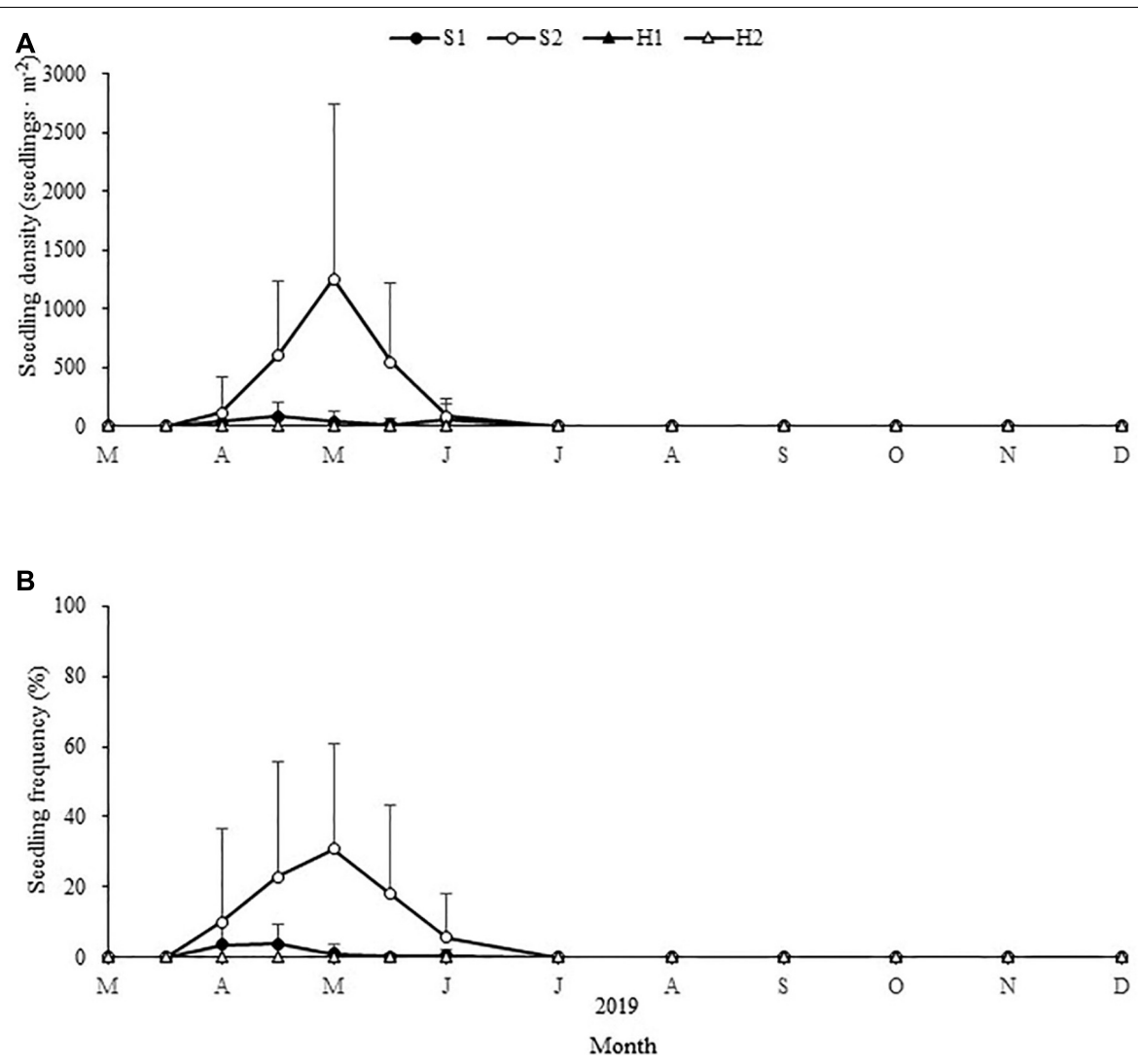

FIGURE 10 | Changes in Zostera japonica seedling densities (A) and seedling frequency (B) at the four study sites from March 2019 to December 2019. Values are mean $\pm \mathrm{SD}(N=7$ cores per site).

Thus, the SLL and HQB populations differed in flowering phenology. Factors that affect the phenology of plants are genes, photoperiod, temperature and precipitation (Forrest and MillerRushing, 2010). Because the photoperiod and precipitation at the four sites in the present study were similar, higher temperature is likely the main reason for the difference in flowering phenology. Temperature is a main influencing factor for many plant growth processes, and in many cases, higher temperatures accelerate plant growth, leading to an earlier progression to the next stage (Saxe et al., 2001; Badeck et al., 2004). Qin et al. (2020) observed that the flowering duration of $Z$. marina in the colder region (5-7.5 months) was longer than in the warmer region (3.5 months). Blok et al. (2018) reported that $Z$. marina reproductive shoots appeared later in the colder regions.

During the flowering periods, there were differences in the allocation to sexual reproduction at the four study sites. At SLL, the flowering frequency, reproductive effort and the potential seed production were greater than at HQB. In addition, the maximum height of reproductive shoots at $S 1$ was lower than at HQB, while the maximum number of spathes per reproductive shoot at S1 was higher than at HQB. These data indicated that the allocation to sexual reproduction was greater at SLL. During the spathe developmental process (Figure 8), the number of female flowers per flowering spathe should be equal to the number seeds per seed spathe if pollination was $100 \%$ successful. However, the number of female flowers per flowering spathe was greater than the number of seeds per seed spathe at the four sites. Pollen limitation is a common reason for this phenomenon (van Tussenbroek et al., 2016). The numbers of female flowers per flowering spathe at S1 and S2 were lower than at $\mathrm{H} 2$. However, the potential seed production levels at these sites were greater than at HQB. van Tussenbroek et al. (2016) reported that the pollination success rate of $Z$. noltei was significant positively correlated with reproductive shoot density $(<600$ shoots $\cdot \mathrm{m}^{-2}$ ). The higher reproductive output at SLL might result from the greater reproductive shoot density compared with at HQB. There was no significantly difference in the reproductive shoot density between $\mathrm{H} 1$ and $\mathrm{H} 2$, but the potential seed production at $\mathrm{H} 1$ was less than at $\mathrm{H} 2$. Therefore, isolated patches (H1) have a much lower seed-set than continuous populations (H2).

Although the potential seed production at SLL was relatively high, the seed density in sediment was still at a low level. The ratio of sediment seed banks to potential seed production was less than $10 \%$ at all four sites, and no stable sediment seed banks were found at HQB. Similar phenomena have been reported previously. Harrison (1993) reported that a large amount of $Z$. marina seeds in a seed bank was lost owing to death and that only a limited number of the seeds remained in the persistent 
seed bank in the sediment. We also observed a large amount of seed coats in SLL. However, we found hardly any seed coat in HQB, which indicates that seeds had disappeared. Their fate is still unknown. We compared the dry weights, wet weights, and moisture contents of Z. japonica seeds at $\mathrm{H} 2$ and $\mathrm{S} 1$, and there were no significant differences (unpublished data). Additionally, the seeds were similar in size. Fishman and Orth (1996) found that seed predation can decrease $Z$. marina seeds by $65 \%$ in a seed bank. Dispersal is an important process in the life history of nearly all plant species and can be facilitated by both abiotic and biotic mechanisms (Sumoski and Orth, 2012). Therefore, the disappearance of seeds in HQB may be to the result of seed predation and dispersal.

Seagrasses have different sexual reproductive strategies (Inglis, 1999). Some species such as Halodule spp. and Cymodocea spp. form seed banks of small seeds with hard shells that can remain dormant for long periods; whereas other species, such as Posidonia spp. and Thalassia spp., form buoyant fruits with large inner non-dormant seeds (Kuo et al., 1990; Kuo and Den Hartog, 2006; Guerrero-Meseguer et al., 2018). Harrison (1991) showed that recently shed Z. marina seeds may undergo physiological and physical dormancy. We found that Z. japonica seeds also experienced dormancy (unpublished data). Thus, seeds do not germinate immediately after maturity. Therefore, seed banks in sediments are important for the successful sexual recruitment of $Z$. japonica. Seed germination of $Z$. japonica at SLL began in the middle of March, and seedling density peaked in mid-April to early May and ended in July, which was similar to Z japonica in the Yellow River Delta (Zhang et al., 2019). No seedlings were found in situ at HQB in the present study; and no seedlings have been observed in monospecific meadows of $Z$. japonica on the southern coast of Korea (Suonan et al., 2017).

In conclusion, we showed that SLL and HQB populations adapted to their habitats and maintained different reproductive strategies. The population of $Z$. japonica in HQB is maintained by asexual reproduction, whereas the $Z$. japonica of SLL relies on asexual and sexual reproduction to maintain its population. The results indicate the necessity of understanding local reproductive strategies before starting restoration and management projects.

\section{REFERENCES}

Abe, M., Yokota, K., Kurashima, A., and Maegawa, M. (2009). Temperature characteristics in seed germination and growth of Zostera japonica Ascherson \& Graebner from Ago Bay, Mie Prefecture, Central Japan. Fish. Sci. 75, 921-927. doi: 10.1007/s12562-009-0123-z

Ackerman, J. D. (2006). "Sexual reproduction of seagrasses: pollination in the marine context," in Seagrasses: Biology, Ecology, and Conservation, eds A. W. D. Larkum, R. J. Orth, and C. M. Duarte (Dordrecht: Springer), 89-109. doi: 10.1007/1-40202983-7_4

Badeck, F.-W., Bondeau, A., Bottcher, K., Doktor, D., Lucht, W., Schaber, J., et al. (2004). Responses of spring phenology to climate change. New Phytol. 162, 295-309. doi: 10.1111/j.1469-8137.2004. 01059.x

Bayer, R. D. (1979). Intertidal zonation of Zostera marina in the Yaquina Estuary, Oregon. Syesis 12, 147-154.
This will help us to choose effective methods for seagrass bed restoration. Owing to the disappearance of seeds in HQB, they should not be used to restore this seagrass meadow. Our research provides fundamental information and guidance for the conservation and restoration of seagrass beds.

\section{DATA AVAILABILITY STATEMENT}

The datasets presented in this article are not readily available because the follow-up research is still in progress. Requests to access the datasets should be directed to yueshidong17@mails.ucas.ac.cn.

\section{AUTHOR CONTRIBUTIONS}

SY and YiZ carried out the experiments and data analysis, and prepared the figures. XZ, SX, YuZ, PZ, and XW prepared materials and carried out the experiments. YiZ and SY participated in the design of the work. SY revised the manuscript. All authors read and approved the final manuscript.

\section{FUNDING}

This research was supported by the National Science \& Technology Basic Work Program (2015FY110600), the National Key R\&D Program of China (2019YFD0901301), the National Natural Science Foundation of China (No. 41606192/41176140), the Key Research Project of Frontier Sciences of CAS (QYZDBSSW-DQC041-1), the International Partners Program of the Chinese Academy of Sciences (133137KYSB20180069), and the Taishan Scholars Program (Distinguished Taishan Scholars).

\section{ACKNOWLEDGMENTS}

We would like to thank Kai Xiao and Gang Li for the help in the field survey, and Mingjie Liu, Yongliang Qiao, and Jingchun Sun for the assistance during the laboratory experiments.

Blok, S. E., Olesen, B., and Krause-Jensen, D. (2018). Life history events of eelgrass Zostera marina L. populations across gradients of latitude and temperature. Mar. Ecol. Prog. Ser. 590, 79-93. doi: 10.3354/meps12479

Conacher, C. A., Poiner, I. R., and Odonohue, M. (1994). Morphology, flowering and seed production of Zostera capricorni Aschers in subtropical Australia. Aquat. Bot. 49, 33-46. doi: 10.1016/0304-3770(94)90004-3

Costanza, R., dArge, R., deGroot, R., Farber, S., Grasso, M., Hannon, B., et al. (1997). The value of the world's ecosystem services and natural capital. Nature 387, 253-260. doi: 10.1038/387253a0

Cullen-Unsworth, L. C., and Unsworth, R. K. F. (2016). Strategies to enhance the resilience of the world's seagrass meadows. J. Appl. Ecol. 53, 967-972. doi: $10.1111 / 1365-2664.12637$

Duffy, J. E. (2006). Biodiversity and the functioning of seagrass ecosystems. Mar. Ecol. Prog. Ser. 311, 233-250. doi: 10.3354/meps311233

Felger, R. S., and McRoy, C. P. (1975). "Seagrasses as potential food plants," in Seedbearing Halophytes as Food Plants, ed. G. F. Sommers (Newark, DE: University of Delaware), 62-68. 
Fishman, J. R., and Orth, R. J. (1996). Effects of predation on Zostera marina L seed abundance. J. Exp. Mar. Biol. Ecol. 198, 11-26. doi: 10.1016/0022-0981(95) 00176-x

Forrest, J., and Miller-Rushing, A. J. (2010). Toward a synthetic understanding of the role of phenology in ecology and evolution. Philos. Trans. R. Soc. Lond. B Biol. Sci. 365, 3101-3112. doi: 10.1098/rstb.2010.0145

Greve, T. M., Krause-Jensen, D., Rasmussen, M. B., and Christensen, P. B. (2005). Means of rapid eelgrass (Zostera marina L.) recolonisation in former dieback areas. Aquat. Bot. 82, 143-156. doi: 10.1016/j.aquabot.2005.03.004

Guerrero-Meseguer, L., Sanz-Lazaro, C., and Marin, A. (2018). Understanding the sexual recruitment of one of the oldest and largest organisms on Earth, the seagrass Posidonia oceanica. PLoS One 13:e0207345. doi: 10.1371/journal.pone. 0207345

Harrison, P. G. (1979). Reproductive strategies in intertidal populations of 2 cooccurring seagrasses (Zostera spp). Can. J. Bot. 57, 2635-2638. doi: 10.1139/ b79-312

Harrison, P. G. (1991). Mechanisms of seed dormancy in an annual population of Zostera marina. Can. J. Bot. 69, 1972-1976. doi: 10.1139/b91-247

Harrison, P. G. (1993). Variations in demography of Zostera marina and Z. noltii on an intertidal gradient. Aquat. Bot. 45, 63-77. doi: 10.1016/0304-3770(93)90 053-y

Henderson, J., and Hacker, S. D. (2015). Buried alive: an invasive seagrass (Zostera japonica) changes its reproductive allocation in response to sediment disturbance. Mar. Ecol. Prog. Ser. 532, 123-136. doi: 10.3354/meps1 1335

Hodoki, Y., Ohbayashi, K., Tanaka, N., and Kunii, H. (2013). Evaluation of genetic diversity in Zostera japonica (Aschers. et Graebn.) for seagrass conservation in brackish lower reaches of the Hii River System, Japan. Estuaries Coasts 36, 127-134. doi: 10.1007/s12237-012-9564- 1

Inglis, G. J. (1999). Variation in the recruitment behaviour of seagrass seeds: implications for population dynamics and resource management. Pac. Conserv. Biol. 5, 256-259. doi: 10.1071/PC000251

Keddy, C. J., and Patriquin, D. G. (1978). An annual form of eelgrass in Nova Scotia. Aquat. Bot. 5, 163-170. doi: 10.1016/0304-3770(78)90059-1

Kendrick, G. A., Waycott, M., Carruthers, T. J. B., Cambridge, M. L., Hovey, R., Krauss, S. L., et al. (2012). The central role of dispersal in the maintenance and persistence of seagrass populations. BioScience 62, 56-65. doi: 10.1525/bio.2012. 62.1 .10

Kuo, J., and Den Hartog, C. (2006). "Seagrass morphology, anatomy, and ultrastructure. Seagrasses: biology, ecology and conservation," in Seagrasses: Biology, Ecology and Conservation, eds A. W. D. Larkum, R. J. Orth, and C. M. Duarte (Dordrecht: Springer), 51-87. doi: 10.1007/1-4020-2983-7_3

Kuo, J., Iizumi, H., Nilsen, B. E., and Aioi, K. (1990). Fruit anatomy, seed germination and seedling development in the Japanese seagrass Phyllospadix (Zosteraceae). Aquat. Bot. 37, 229-245. doi: 10.1016/0304-3770(90)90072-s

Larkum, A. W. D., Collett, L. C., and Williams, R. J. (1984). The standing stock, growth and shoot production of Zostera capricorni Aschers in Botany Bay, New South Wales, Australia. Aquat. Bot. 19, 307-327. doi: 10.1016/0304-3770(84) 90046-9

Laushman, R. H. (1993). Population genetics of hydrophilous angiosperms. Aquat. Bot. 44, 147-158. doi: 10.1016/0304-3770(93)90069-9

Lee, K.-S., Park, J.-I., Kim, Y. K., Park, S. R., and Kim, J.-H. (2007). Recolonization of Zostera marina following destruction caused by a red tide algal bloom: the role of new shoot recruitment from seed banks. Mar. Ecol. Prog. Ser. 342, 105-115. doi: 10.3354/meps342105

Lee, S., Ma, S., Lim, Y., Choi, H. K., and Shin, H. (2004). Genetic diversity and its implications in the conservation of endangered Zostera japonica in Korea. J. Plant Biol. 47, 275-281. doi: 10.1007/bf03030519

Lefcheck, J. S., Wilcox, D. J., Murphy, R. R., Marion, S. R., and Orth, R. J. (2017). Multiple stressors threaten the imperiled coastal foundation species eelgrass (Zostera marina) in Chesapeake Bay, USA. Glob. Change Biol. 23, 3474-3483. doi: $10.1111 /$ gcb.13623

Les, D. H. (1988). Breeding systems, population structure, and evolution in hydrophilous angiosperms. Ann. Mo. Bot. Gard. 75, 819-835. doi: 10.2307/ 2399370

Marba, N., and Walker, D. I. (1999). Growth, flowering, and population dynamics of temperate Western Australian seagrasses. Mar. Ecol. Prog. Ser. 184, 105-118. doi: $10.3354 /$ meps 184105
McKenzie, L. J. (1994). Seasonal changes in biomass and shoot characteristics of a Zostera capricorni Aschers - dominant meadow in Cairns Harbour, Northern Queensland. Aust. J. Mar. Freshw. Res. 45, 1337-1352. doi: 10.1071/mf9941337

Miki, S. (1933). On the sea-grasses in Japan: 1. Zostera and Phyllospadix, with special reference to morphological and ecological characters. Bot. Mag. 47, 842-862.

Olsen, J. L., Rouze, P., Verhelst, B., Lin, Y.-C., Bayer, T., Collen, J., et al. (2016). The genome of the seagrass Zostera marina reveals angiosperm adaptation to the sea. Nature 530, 331-335. doi: 10.1038/nature16548

Phillips, R. C. (1972). Ecological Life History of Zostera marina L. (Eelgrass) in Puget Sound, Washington. Ph.D. Dissertation, University of Washington, Seattle, WA, 154.

Procaccini, G., and Mazzella, L. (1998). Population genetic structure and gene flow in the seagrass Posidonia oceanica assessed using microsatellite analysis. Mar. Ecol. Prog. Ser. 169, 133-141. doi: 10.3354/meps169133

Qin, L. Z., Kim, S. H., Song, H. J., Suonan, Z., Kim, H., Kwon, O., et al. (2020). Influence of regional water temperature variability on the flowering phenology and sexual reproduction of the seagrass Zostera marina in Korean coastal waters. Estuaries Coasts 43, 449-462. doi: 10.1007/s12237-019-00569-3

Rasheed, M. A. (1999). Recovery of experimentally created gaps within a tropical Zostera capricorni (Aschers.) seagrass meadow, Queensland Australia. J. Exp. Mar. Biol. Ecol. 235, 183-200. doi: 10.1016/s0022-0981(98)00158-0

Rasheed, M. A. (2004). Recovery and succession in a multi-species tropical seagrass meadow following experimental disturbance: the role of sexual and asexual reproduction. J. Exp. Mar. Biol. Ecol. 310, 13-45. doi: 10.1016/j.jembe.2004.03. 022

Reusch, T. B. H. (2003). Floral neighbourhoods in the sea: how floral density, opportunity for outcrossing and population fragmentation affect seed set in Zostera marina. J. Ecol. 91, 610-615. doi: 10.1046/j.1365-2745.2003.00787.x

Reynolds, L. K., Waycott, M., and McGlathery, K. J. (2013). Restoration recovers population structure and landscape genetic connectivity in a dispersal-limited ecosystem. J. Ecol. 101, 1288-1297. doi: 10.1111/1365-2745.12116

Reynolds, L. K., Waycott, M., McGlathery, K. J., Orth, R. J., and Zieman, J. C. (2012). Eelgrass restoration by seed maintains genetic diversity: case study from a coastal bay system. Mar. Ecol. Prog. Ser. 448, 223-233. doi: 10.3354/ meps09386

Robertson, A. I., and Mann, K. H. (1984). Disturbance by ice and life-history adaptations of the seagrass Zostera marina. Mar. Biol. 80, 131-141. doi: 10.1007/ bf02180180

Saxe, H., Cannell, M. G. R., Johnsen, B., Ryan, M. G., and Vourlitis, G. (2001). Tree and forest functioning in response to global warming. New Phytol. 149, 369-399. doi: 10.1046/j.1469-8137.2001.00057.x

Shafer, D. J., Kaldy, J. E., and Gaeckle, J. L. (2014). Science and management of the introduced seagrass Zostera japonica in North America. Environ. Manag. 53, 147-162. doi: 10.1007/s00267-013-0172-Z

Short, F. T., and Coles, R. G. (2001). Global Seagrass Research Methods. Amsterdam: Elsevier Science Press.

Short, F. T., Kosten, S., Morgan, P. A., Malone, S., and Moore, G. E. (2016). Impacts of climate change on submerged and emergent wetland plants. Aquat. Bot. 135, 3-17. doi: 10.1016/j.aquabot.2016.06.006

Short, F. T., Polidoro, B., Livingstone, S. R., Carpenter, K. E., Bandeira, S., Bujang, J. S., et al. (2011). Extinction risk assessment of the world's seagrass species. Biol. Conserv. 144, 1961-1971. doi: 10.1016/j.biocon.2011.04.010

Sumoski, S. E., and Orth, R. J. (2012). Biotic dispersal in eelgrass Zostera marina. Mar. Ecol. Prog. Ser. 471, 1-10. doi: 10.3354/meps10145

Suonan, Z., Kim, S. H., Qin, L. Z., and Lee, K. S. (2017). Reproductive strategy of the intertidal seagrass Zostera japonica under different levels of disturbance and tidal inundation. Estuar. Coast. Shelf Sci. 197, 185-193. doi: 10.1016/j.ecss.2017. 08.031

Tomlinson, P. B. (1974). Vegetative morphology and meristem dependence - the foundation of productivity in seagrasses. Aquaculture 4, 107-130. doi: 10.1016/ 0044-8486(74)90027-1

Unsworth, R. K. F., Collier, C. J., Waycott, M., McKenzie, L. J., and CullenUnsworth, L. C. (2015). A framework for the resilience of seagrass ecosystems. Mar. Pollut. Bull. 100, 34-46. doi: 10.1016/j.marpolbul.2015.08.016

Unsworth, R. K. F., Williams, B., Jones, B. L., and Cullen-Unsworth, L. C. (2017). Rocking the boat: damage to eelgrass by swinging boat moorings. Front. Plant Sci. 8:1309. doi: 10.3389/fpls.2017.01309 
van Katwijk, M. M., Thorhaug, A., Marba, N., Orth, R. J., Duarte, C. M., Kendrick, G. A., et al. (2016). Global analysis of seagrass restoration: the importance of large-scale planting. J. Appl. Ecol. 53, 567-578. doi: 10.1111/1365-2664.12562

van Tussenbroek, B. I., Soissons, L. M., Bouma, T. J., Asmus, R., Auby, I., Brun, F. G., et al. (2016). Pollen limitation may be a common Allee effect in marine hydrophilous plants: implications for decline and recovery in seagrasses. Oecologia 182, 595-609. doi: 10.1007/s00442-016-3665-7

Waycott, M., Duarte, C. M., Carruthers, T. J. B., Orth, R. J., Dennison, W. C., Olyarnik, S., et al. (2009). Accelerating loss of seagrasses across the globe threatens coastal ecosystems. Proc. Natl. Acad. Sci. U.S.A. 106, 12377-12381. doi: 10.1073/pnas.0905620106

Williams, S. L. (1990). Experimental studies of Caribbean seagrass bed development. Ecol. Monogr. 60, 449-469. doi: 10.2307/1943015

Xu, S. C., Wang, P. M., Zhou, Y., Zhang, X. M., Gu, R. T., Liu, X. J., et al. (2018). New insights into different reproductive effort and sexual recruitment contribution between two geographic Zostera marina L. populations in temperate China. Front. Plant Sci. 9:15. doi: 10.3389/fpls.2018.00015

Xu, S., Xu, S. C., Zhou, Y., Zhao, P., Yue, S. D., Song, X. Y., et al. (2019). Single beam sonar reveals the distribution of the eelgrass Zostera marina L. and threats from the green tide algae Chaetomorpha linum K. in Swan-Lake lagoon (China). Mar. Pollut. Bull. 145, 611-623. doi: 10.1016/j.marpolbul.2019.06.022

$\mathrm{Xu}$, Q. Z., Liu, B. J., and Zhou, Y. (2018). Does the eelgrass meadow influence the macrobenthic community structure in Swan Lake, Northern China? Mar. Biodivers. 48, 1337-1344. doi: 10.1007/s12526-016-0601-3

York, P. H., Carter, A. B., Chartrand, K., Sankey, T., Wells, L., and Rasheed, M. A. (2015). Dynamics of a deep-water seagrass population on the Great Barrier Reef: annual occurrence and response to a major dredging program. Sci. Rep. 5:13167. doi: 10.1038/srep13167

Zhang, X. M., Lin, H. Y., Song, X. Y., Xu, S. C., Yue, S. D., Gu, R. T., et al. (2019). A unique meadow of the marine angiosperm Zostera japonica, covering a large area in the turbid intertidal Yellow River Delta, China. Sci. Total Environ. 686, 118-130. doi: 10.1016/j.scitotenv.2019. 05.320

Zhang, X. M., Zhou, Y., Adams, M. P., Wang, F., Xu, S. C., Wang, P. M., et al. (2020a). Plant morphology and seed germination responses of seagrass (Zostera japonica) to water depth and light availability in Ailian Bay, northern China. Mar. Environ. Res. 162:105082. doi: 10.1016/j.marenvres.20 20.105082

Zhang, X. M., Zhou, Y., Liu, P., Wang, F., Liu, B. J., Liu, X. J., et al. (2014). Temporal pattern in the bloom-forming macroalgae Chaetomorpha linum and Ulva pertusa in seagrass beds, Swan Lake lagoon, North China. Mar. Pollut. Bull. 89, 229-238. doi: 10.1016/j.marpolbul.2014.09.054

Zhang, X. M., Zhou, Y., Liu, P., Wang, F., Liu, B. J., Liu, X. J., et al. (2015). Temporal pattern in biometrics and nutrient stoichiometry of the intertidal seagrass Zostera japonica and its adaptation to air exposure in a temperate marine lagoon (China): implications for restoration and management. Mar. Pollut. Bull. 94, 103-113. doi: 10.1016/j.marpolbul.2015.03.004

Zhang, X. M., Zhou, Y., Xu, S. C., Wang, P. M., Zhao, P., Yue, S. D., et al. (2020b). Differences in reproductive effort and sexual recruitment of the seagrass Zostera japonica between two geographic populations in northern China. Mar. Ecol. Prog. Ser. 638, 65-81. doi: 10.3354/meps 13248

Zhou, Y., Liu, P., Liu, B. J., Liu, X. J., Zhang, X. M., Wang, F., et al. (2014). Restoring eelgrass (Zostera marina L.) habitats using a simple and effective transplanting technique. PLoS One 9:e92982. doi: 10.1371/journal.pone.0092982

Zhou, Y., Liu, X. J., Liu, B. J., Liu, P., Wang, F., Zhang, X. M., et al. (2015). Unusual pattern in characteristics of the eelgrass Zostera marina L. in a shallow lagoon (Swan Lake), north China: implications on the importance of seagrass conservation. Aquat. Bot. 120, 178-184. doi: 10.1016/j.aquabot.2014.05.014

Conflict of Interest: XW was employed by the company Mashan Group Co., Ltd.

The remaining authors declare that the research was conducted in the absence of any commercial or financial relationships that could be construed as a potential conflict of interest.

Copyright (c) 2020 Yue, Zhang, Xu, Zhang, Zhao, Wang and Zhou. This is an openaccess article distributed under the terms of the Creative Commons Attribution License (CC BY). The use, distribution or reproduction in other forums is permitted, provided the original author(s) and the copyright owner(s) are credited and that the original publication in this journal is cited, in accordance with accepted academic practice. No use, distribution or reproduction is permitted which does not comply with these terms. 